\title{
OPTIMIZATION OF PROPHYLACTIC ARRANGEMENTS IN CHILDREN WITH HYPOPLASIA OF DENTAL ENAMEL
}

\author{
Svetlana Liubarets \\ Department of pediatric and preventative dentistry \\ Bogomolets National Medical University, \\ 13 Shevchenko blvd., Kyiv, Ukraine, 01601 \\ slub@ukr.net \\ Nataliia Bidenko \\ Department of pediatric and preventative dentistry \\ Bogomolets National Medical University, \\ 13 Shevchenko blvd., Kyiv, Ukraine, 01601 \\ natali_bidenko@voliacable.com
}

\begin{abstract}
Aim of research. To raise the effectiveness of anticarious properties of oral cavity in children with enamel hypoplasia by introduction of the complex of arrangements, directed on optimization of the oral cavity hygiene, level of secretory immunoglobulin A ( $\operatorname{Sg} \mathrm{A})$ and the content of mineral components of oral liquid (calcium and orthophosphates).

Materials and methods. Object of research - enamel hypoplasia of the permanent teeth. Subject of research - hygienic status of the oral cavity, level of general calcium, orthophosphates, sIgA in the oral liquid. Methods of research: vital coloration of enamel, transillumination, photometric, immune-enzyme method, indices of hygienic status of the oral cavity (Green-Vermillion (1964) index, Silness-Loe (1964, 1967) index).

There was carried out an assessment of hygienic status of the oral cavity, determination of the level of calcium, orthophosphates and SIgA in the oral liquid of 45 children, 6-14 years old (group № 1 - 21 persons, group № 2 - 24 persons). Group №1 - children, who underwent the complex of prophylactic arrangements that included recommendations as to the choice of means and subjects for the oral cavity care and teaching the standard method of teeth brushing. Group № 2 - children, who additionally used remineralizing cream on the water base with casein phosphopeptide - amorphous calcium phosphate (CPP-ACP) (Certificate on the state registration № 10014/2010 of 03.12.2010).

Results. Hygienic status of the oral cavity of children from the both groups was assessed as "unsatisfactory" one according to Green-Vermillion index and as "bad" one according to Silness-Loe index. After prophylactic arrangements the oral cavity status was improved in children of the group № 1: Green-Vermillion $(\mathrm{p}=0,0013)$ and Silness-Loe $(\mathrm{p}=0,0002)$ indices essentially decreased. In children of the group № 2 after prophylactic arrangements hygienic status of the oral cavity was improved more essentially: GreenVermillion ( $p=0,0002)$ and Silness-Loe $(p=0,0002)$ indices reliably decreased. Prescription of remineralizing cream to the children of group № 2 reliably raised the content of calcium $(\mathrm{p}=0,0051)$ and $\operatorname{sIg} \mathrm{A}$ in the oral liquid $(\mathrm{p}=0,001)$. Orthophosphates level did not essentially change in both groups.

Conclusions. Introduction of the complex of prophylactic arrangements with additional use of remineralizing preparation favored the more essential improvement of the oral cavity hygiene, raise of calcium and SIgA in the oral liquid.

Keywords: prophylaxis of caries, enamel hypoplasia, calcium of the oral liquid, orthophosphates of the oral liquid, secretory immunoglobulin A of the oral liquid.
\end{abstract}

\section{Introduction}

The study of features of injury of the hard teeth tissues of noncarious genesis is an actual question of the modern child therapeutic dentistry. The hard tissues disorders including hypoplasia of enamel are more than $9 \%$ among diseases that lead to premature destruction and extraction of teeth in children [1]. According to the data of Ukrainian researchers, the prevalence of enamel hypoplasia of the permanent teeth is within 16,5-40\% [2-5]. According to international classification of dental diseases (MCD-D), enamel hypoplasia (K00.40) is assigned to the group "Disorders of teeth formation" (K00.4). There are disorders of permanent teeth in children that are a consequence of metabolic disorders that appear as the result of influence of diverse endogenous and exogenous factors during the period of intrauterine development or first years of the life [6]. 
Caries is a main complication of enamel hypoplasia [6, 7]. Enamel hypoplasia appears as the result of disorder of mineral metabolism in the period of teeth formation and development, and caries injuries the hard tissues of already formed teeth, first of all leading to destruction of incorrectly formed hard tissues [6]. So, enamel hypoplasia is an essential risk factor of teeth caries development. At the same time the state of local immunity of the oral cavity, especially the level of secretory immunoglobulin A (sIgA) and mineralizing potential of oral liquid (OL) have the essential influence on the teeth injury by caries [6].

In the dental literature are presented only separate researches, devoted to the complex assessment of the problem of injury of teeth hard tissues in children, especially the clinical course of the system enamel hypoplasia, its complications (caries) and the ways of prophylaxis.

\section{Aim of research}

To raise the effectiveness of anticarious properties of oral liquid in children with enamel hypoplasis by introduction of complex of arrangements, directed on optimization of the oral cavity hygiene, sIgA level and mineral components (calcium, orthophosphates) content in the oral cavity.

\section{Materials and methods of research}

There were examined 45 children 45 (II-III pediatric group of health [6]) 6-14 years old (mean age of examined $-8,76 \pm 1,99$ years) with system hypoplasia of the permanent teeth. Inclusion of children into research was carried out on condition of the informed written consent of parents and patients. Before the start of research, according to the points of "Helsinki Declaration" (2000), parents of children and older children were informed about the aim of research, methods, potential benefit and risk, possible discomfort at diagnostics and other manipulations. Anamnestic data of children were received from parents or outpatient cards of clinic. Determination of forms of enamel hypoplasia in examined children was carried out according to classification of Fedorov Y. A. and co-authors (1997) [6]. Examination was realized at the department of child therapeutic dentistry and prophylaxis of dental diseases of NMU of Bogomolets O. O. and included the collection of anamnesis, interrogation of children and parents, external examination, examination of the oral cavity, determination of parameters and Green-Vermillion (1964) and Silness-Loe $(1964,1967)$ indices; sIgA, calcium and orthophosphates level in the oral liquid (OL) that was collected in the morning fasting before and after prophylactic arrangements. Determination of sIgA in the liquid phase of OL was carried out in laboratory of pathophysiology and immunology of SI "Institute of otolaryngology of professor O. S. Kolomijchenko, NAMS of Ukraine" according to the instructions of producer, using the set of reagents by "Hemma-Medica" and immune-enzyme analyzer Star Fax 2100 (USA). Determination of calcium and orthophosphates content in OL of children was carried out in laboratory of SI "NSCRM, NAMS of Ukraine" by photometric method, using reagents by "Human" (Germany). The method of vital coloration of enamel and transillumination was used for differential diagnostics of hypoplasia and caries [6].

For improvement of hygienic status of the oral cavity was offered the complex of prophylactic arrangements including:

1) teaching the oral cavity care with the further control at repeated visits;

2) recommendations as to the choice of means and subjects of hygiene;

3) regular use of remineralizing preparation.

The division of examined in groups was the following: group № $1-21$ children with the system enamel hypoplasia, who were taught the correct oral cavity care, group № $2-24$ children, who used reminaralizing cream (RC) on the water base that contains casein phosphopeptide-amorphous calcium phosphate (CPP-ACP) (“Certificate on state registration № 10014/2010 of 03.12.2010), except the study of hygienic skills. Methodology of the use corresponded to the producer's recommendations and was the following: to brush teeth with ordinary tooth paste, to rinse mouth with water, to put the thin layer of $\mathrm{RC}$ on teeth by finger or brush and not to close mouth during three minutes to avoid flushing of cream, then to distribute RC evenly over the whole oral cavity by tongue. It is recommended to keep RC in the oral cavity for the maximal time (minimally 5 minutes) for intensifying its action, then to remove saliva with remains of RC and do not take food and 
drinks during 30 minutes. The surface application of RC provides an additional protection of teeth hard tissues, it neutralizes the products of life activity of acid-forming bacteria that are included in the tooth plaque, neutralizes the influence of acids that enter into the oral cavity from the other external and internal sources. It was recommended to use cream 1 time a day during month twice a year. There are presented data for assessment of effectiveness of the offered prophylactic complex in examined children in 2 years after its introduction.

Statistical processing of information was carried out using MS Excel 10 program.

\section{Results of research}

At examination of children with system enamel hypoplasia the spotted form was detected in $72 \%$ of patients from the group № 1 and in $69 \%$ of the group № 2; erosive form was diagnosed in 8 and $10 \%$ of examined, respectively, striated one - in 20 and $21 \%$, respectively.

The results of interrogation of children testified that almost none of examined possessed skills of the correct teeth brushing in full: $83 \%$ of examined brushed teeth twice a day- in evening and in the morning, $12 \%$ - once a day, $5 \%$ - irregularly. Only $34 \%$ of children used such subjects and means of hygiene as conditioners and flosses.

Hygienic status of the oral cavity of children of both groups (№ 1 and № 2) corresponded to the criterion "unsatisfactory" of Green-Vermillion index $(1,89 \pm 0,83$ and $1,70 \pm 0,83$, respectively)

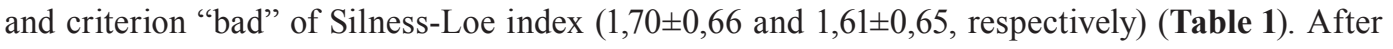
prophylactic arrangements in children of the group № 1 hygienic status of the oral cavity essentially increased: Green-Vermillion $(p=0,0013)$ and Silness-Loe $(p=0,0002)$ indices essentially decreased. In children of the group № 2 after prophylactic arrangements hygienic status of the oral cavity increased more essentially on Green-Vermillion index $(\mathrm{p}=0,0002)$, and did not differ from the data of group № 1 on Silness-Loe index $(\mathrm{p}=0,0002)$.

Table 1

Rates of hygienic indices in children with system enamel hypoplasia before and after prophylactic arrangements

\begin{tabular}{ccccc}
\hline $\begin{array}{c}\text { Group of examined } \\
\text { (number of persons) }\end{array}$ & \multicolumn{2}{c}{$\begin{array}{c}\text { Green-Vermillion index }(\mathbf{M} \pm \mathbf{m}) \\
\text { before }\end{array}$} & after & \multicolumn{2}{c}{ Silness-Loe index (M $\pm \mathbf{m})$} \\
before & After \\
\hline $\begin{array}{c}\text { № 1 } \\
(\mathrm{n}=21)\end{array}$ & $1,89 \pm 0,83$ & $\begin{array}{l}1,22 \pm 0,43^{*} \\
(\mathrm{p}=0,0013)\end{array}$ & $1,70 \pm 0,66$ & $\begin{array}{l}1,09 \pm 0,42^{*} \\
(\mathrm{p}=0,0002)\end{array}$ \\
№ 2 & & $0,82 \pm 0,53^{*}$ & & $0,99 \pm 0,28^{*}$ \\
$(\mathrm{n}=24)$ & $1,70 \pm 0,83$ & $(\mathrm{p}=0,0002)$ & $1,61 \pm 0,65$ & $(\mathrm{p}=0,0002)$
\end{tabular}

Note: *-reliable difference of rates before and after prophylactic arrangements within the one examined group

Concentration of calcium and orthophosphates in OL of children of the group № 1 and № 2 was $1,32 \pm 0,29 \mathrm{mmol} / 1$ and $1,33 \pm 0,40 \mathrm{mmol} / 1 ; 3,43 \pm 1,04 \mathrm{mmol} / 1$ and 3,46 $\pm 0,95 \mathrm{mmol} / 1$, respectively (Table 2). After prophylactic arrangements in children of the group № 2 calcium level in the oral cavity increased more significantly $(\mathrm{p}=0,0051)$.

Table 2

Calcium and orthophosphates content in the oral liquid of children with system enamel hypoplasia before and after prophylactic arrangements

\begin{tabular}{|c|c|c|c|c|}
\hline \multirow{2}{*}{$\begin{array}{l}\text { Group of examined } \\
\text { (number of persons) }\end{array}$} & \multicolumn{2}{|c|}{ Calcium, mmol/l $(M \pm m)$} & \multicolumn{2}{|c|}{ Orthophosphates, $\mathrm{mmol} / \mathrm{l}(\mathrm{M} \pm \mathrm{m})$} \\
\hline & before & after & Before & After \\
\hline $\begin{array}{c}\text { № } 1 \\
(\mathrm{n}=21)\end{array}$ & $1,32 \pm 0,29$ & $\begin{array}{l}1,47 \pm 0,26^{*} \\
(p=0,0064)\end{array}$ & $3,43 \pm 1,04$ & $3,54 \pm 0,92$ \\
\hline $\begin{array}{c}\text { № } 2 \\
(\mathrm{n}=24)\end{array}$ & $1,33 \pm 0,40$ & $\begin{array}{l}1,82 \pm 0,72 * \\
(p=0,0051)\end{array}$ & $3,46 \pm 0,95$ & $4,4 \pm 0,79$ \\
\hline
\end{tabular}

Note: * - the reliable difference of rates before and after prophylactic arrangements within the one examined group 
sIgA level in OL of examined children with enamel hypoplasia was moderately decreased in comparison with the lower limit of referent values and was in the groups № 1 and № $2985,85 \pm 649,01 \mathrm{mcg} / \mathrm{ml}$ and 930,41 $\pm 662,95 \mathrm{mcg} / \mathrm{ml}$, respectively (Table 3). In children of the group № 2 after prophylactic arrangements the sIgA content in the oral liquid reliably increased $(p=0,001)$, whereas in children of the group № 1 it did not essentially change.

Table 3

sIgA content in the oral liquid of children with system enamel hypoplasia before and after prophylactic arrangements

\begin{tabular}{|c|c|c|}
\hline \multirow{2}{*}{ Group of examined (number of persons) } & \multicolumn{2}{|c|}{$\operatorname{sIgA}, \mathrm{mcg} / \mathrm{ml}(\mathrm{M} \pm \mathrm{m})$} \\
\hline & before & After \\
\hline $\begin{array}{c}\text { № } 1 \\
(\mathrm{n}=21)\end{array}$ & $985,85 \pm 649,01$ & $989,85 \pm 642,39$ \\
\hline $\begin{array}{c}\text { № } 2 \\
(\mathrm{n}=24)\end{array}$ & $930,41 \pm 662,95$ & $\begin{array}{c}1163,75 \pm 518,48^{*} \\
\quad(p=0,001)\end{array}$ \\
\hline
\end{tabular}

Note: * the reliable difference of rates before and after prophylactic arrangements within the one examined group

\section{Discussion of the results of research}

The study of hygienic status of the oral cavity in children with system enamel hypoplasia testifies to its significant worsening: in children of the groups № 1 and № 2 it corresponded to the criterion "unsatisfactory" of Green-Vermillion index $(1,89 \pm 0,83$ and $1,70 \pm 0,83$, respectively) and criterion "bad" according to Silness-Loe index $(1,70 \pm 0,66$ and 1,61 $\pm 0,65$, respectively). Our data correspond to the literary ones as to the hygienic status of the oral cavity in children with system enamel hypoplasia $[2,5]$. The higher rates of hygienic indices that testify to the bad hygiene of the oral cavity are caused by several factors, including morphological changes of enamel structure [6]. At hypoplasia the enamel disorders are determined not only in the area of visible changes but also on the whole enamel area adjacent to the injury zone. On the limit of transfer of intact enamel in hypoplastic area the number of pores of the different seizes and forms increases that favors fixation of the diverse microflora in them that can condition the complications, especially, caries. In examined children were revealed the spotted, erosive striated forms of enamel hypoplasia with predomination of spotted one. Spots were surface, rough at zonding, with transformed color that testifies to the amelogenesis disorder in the period of enamel formation. For the aforesaid forms of hypoplasia as opposite to the smooth enamel surface is typical the more adhesion of microflora that is an essential factor of worsening of the oral cavity hygiene.

Taking into account the aforesaid, we can state that individual hygiene of the oral cavity is an important component of prophylaxis of caries on the background of enamel hypoplasia. That is why there was carried out a lesson with patients aimed at the teaching the correct care of the oral cavity, use means and subjects of hygiene taking into account the age and dental status. Among the main means of hygiene were recommended the therapeutic and preventive tooth pastes that influence mineralization of tooth tissues and contain compounds of calcium, phosphates and fluorine. Among the additional means of hygiene were prescribed conditioners with anticarious effect; among subjects of hygiene - tooth brushes of medium stiffness and dental flosses. Children received recommendations as to the correct nutrition with limitation of the simple carbohydrates in ration.

In examined children of the group № 1 and № 2 the level of calcium and orthophosphates in OL was on the lower limit of normative values [8]. Our results as to the calcium level in OL (in children

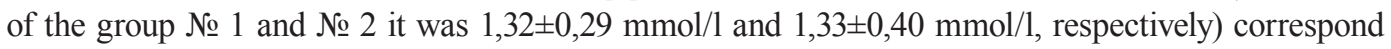
to the data [9], received at observation over children without teeth formation disorders: in dwellers of regions with the high level of environment pollution the calcium level was $1,25 \pm 0,08 \mathrm{mmol} / \mathrm{l}$ and essentially differed from the rate of dwellers with the low level of pollution $-3,17 \pm 0,12 \mathrm{mmol} / \mathrm{l}$. As to the content oforthophosphates in OL, the received results in the group № 1 and № 2 (3,43 $\pm 1,04$ mmol/1 and 
$3,46 \pm 0,95 \mathrm{mmol} / \mathrm{l}$, respectively) also correspond to the results [9] of examination of children - dwellers of regions with the high level of environment pollution $(3,54 \pm 0,32 \mathrm{mmol} / \mathrm{l})$.

As it is known, at enamel hypoplasia takes place the decrease of calcium content in OL that influences the disorder of penetrative ability of membranes of epithelial cells and causes the worsening of conditions for transepithelial passage of SIgA dimeric form and decrease of its concentration in OL [10]. sIgA level in OL of examined children with enamel hypoplasia before prophylactic arrangements was moderately decreased in comparison with the lower limit of the known normative values [10] and essentially grew at prophylactic arrangements in the group № 2 $(\mathrm{p}=0,001)$. At the same time our results differ from the data of A. I. Propyaeva (2013), received at examination of children with system enamel hypoplasia [11], according to which sIgA level in these children did not exceed the normative values by $25 \%$.

The offered complex of prophylactic arrangements in children of the group № 2 with use of RC that consists of casein phosphopeptide (CPP) and amorphous calcium phosphate (ACP), essentially improved hygienic status of the oral cavity, improved calcium and SIgA level. Casein phosphopeptide keeps calcium and phosphate in amorphous non-crystal state and provides the high adhesion of preparation to the tooth hard tissues, pellicle, to the components of plaque and soft tissues of the oral cavity and due to that provides prolonged effect of preparation. CPP-ACP complex slowly releases in the medium around tooth the ions of calcium and phosphorus and provides the gradient of their concentration, necessary for displacement to the subsurface zone of demineralization nidus [12]. CPP-ACP complex is able also to modify the properties of biofilm at the expense of fixation of Streptococcus mutans molecules, increase of number of $\mathrm{Ca}^{2+}$ ions in biofilm with inhibition of its enzymatic function and provision of protein and phosphate buffering of $\mathrm{pH}$ liquid that is included in film (that inhibits the growth of acid-forming microorganisms in the conditions of excessive amount of fermented carbohydrates) [13].

The received results as to effectiveness of RC use in children correspond to the experimental and clinical literary data. In experiment on animals were proved that casein phosphopeptide-amorphous calcium phosphate favors remineralization of enamel [14]. RC use demonstrated the evident therapeutic effect at remineralization of noncarious injuries of the teeth hard tissues [15] and decreased the intensity of clinical symptoms, increased resistance of enamel that was determined by the test of enamel resistance $(p<0,001)$, increased mineralizing potential of saliva $(\mathrm{p}=0,007)$. Positive influence of $\mathrm{RC}$ on the process of mineralization of the teeth hard tissues at caries or noncarious injuries was proved by several other authors in the conditions of experiment and in vivo [16-21]. We must note, that several authors [14, 20] indicate the more effectiveness of RC at its use in the complex with phosphorus-containing preparations.

Our researches were not directed on determination of remineralizing properties of RC in children with enamel hypoplasia but their results proved the increase of calcium level in the oral liquid after its use and as the result the growth of $\operatorname{sigA}$ level that has prophylactic effect relative to development of caries in this contingent of children.

Thus, our results testify that the offered complex of arrangements, directed on optimization of caries prophylaxis in examined children with enamel hypoplasia, can be recommended for introduction into the practical activity of the dental departments of medical institutions.

\section{Conclusions}

1. The study of hygienic status of the oral cavity in children with system enamel hypoplasia testifies to its low level at enamel hypoplasia: in children of the group № 1 and № 2 it corresponded to the criterion "unsatisfactory" according to Green-Vermillion index $(1,89 \pm 0,83$ and $1,70 \pm 0,83$, respectively) and to the criterion "bad" according to Silness-Loe index $(1,70 \pm 0,66$ and $1,61 \pm 0,65$, respectively).

2. There was established the high direct effectiveness of the offered complex of prophylactic arrangements (teaching hygienic habits - group № 1, additional use of remineralizing cream - group № 2) as to hygienic status of the oral cavity in examined children. In groups № 1 and № 2 Green-Vermillion index essentially decreased ( $\mathrm{p}=0,0013$ and $\mathrm{p}=0,0002$, respectively) 
and Silness-Loe index ( $\mathrm{p}=0,0002$ for both groups). Prophylactic arrangements in children of the group № 2 with the use of RC improved the hygienic status of the oral cavity more essentially comparing with children of the group № 1 .

3. Before prescription of prophylactic arrangements the calcium and orthophosphates level in oral liquid of children of the group № 1 and № 2 did not essentially differ and was, respectively, $32 \pm 0,29$ and 1,33 $\pm 0,40 \mathrm{mmol} / 1$ and $3,43 \pm 1,04$ and 3,46 $\pm 0,95 \mathrm{mmol} / 1$. Prophylactic arrangements did not essentially influence the orthophosphates level but favored the reliable growth of calcium level in the oral liquid more in the group № 2 ( $p=0,0064$ and $p=0,0051$, respectively).

4. sIgA level in the oral liquid of examined children on the background of prophylaxis essentially grew in children of the group № $2(p=0,001)$, that testifies to the effectiveness of RC use.

\section{Acknowledgments}

We express gratitude to the workers of laboratory of pathophysiology and immunology of SI "Institute of otolaryngology of professor O. S. Kolomijchenko, NAMS of Ukraine" and laboratory of SI "NSCRM, NAMS of Ukraine" for the help in realization of research.

\section{References}

[1] Bezvushko, Je. V., Ugryn, M. M., Popovych, Z. B. (2007). Porushennja rozvytku ta formuvannja zubiv. Lviv: GalDent. Ukrai'na, 72.

[2] Voljak, L. M. (2013). Profilaktyka ta likuvannja systemnoi' gipoplazii' emali postijnyh zubiv u ditej z endemichnym zobom. Odesa, 20.

[3] Kril', I. A., Rozhko, M. M. (2011). Poshyrenist' systemnoi’ gipoplazii' emali u shkoljariv m. Ivano-Frankivs'ka. Gal. likar. Visnyk,18 (2), 53-55.

[4] Ljubarec', S. F. (2013). Rozpovsjudzhenist' vad tverdyh tkanyn zubiv u ditej, jaki majut' status postrazhdalyh vid naslidkiv avarii' na ChAES. Suchasni aspekty vijs'kovoi' stomatologii'. Kyi'v, II, 100-103.

[5] Liubarets, S. (2016). Dental status of children with the teeth formation disorders. Eureka: Health Sciences, 2, 18-23. doi: 10.21303/2504-5679.2016.00089

[6] Homenko, L. A., Kisel'nikova, L. P., Smoljar, N. I., Chajkovskij, Ju. B., Vasil'ev, A. Ju., Ostapko, E. I. et. al. (2010). Terapevticheskaja stomatologija detskogo vozrasta. Kiev: Kniga pljus, Ukraina, 804.

[7] Hong, L., Levy, S. M., Warren, J. J., Broffitt, B. (2009). Association between Enamel Hypoplasia and Dental Caries in Primary Second Molars: A Cohort Study. Caries Research, 43 (5), 345-353. doi: 10.1159/000231571

[8] Danilova, L. A., Chajka, N. A. (2012). Biohimija polosti rta. Sankt-Peteburg: SpecLit, 62.

[9] Bezvushko, E. V. (2014). Vmist mineral'nyh komponentiv u rotovij ridyni ditej, jaki prozhyvajut' u riznyh ekologichnyh umovah. Novyny stomatologii', 1 (78), 96-98.

[10] Chepel', Je., Hajni, M., Misbah, S., Snovden, N. (2008). Osnovy klinicheskoj immunologii. Moscow «GOJeTAR - Media», 416.

[11] Propjaeva, A. I. (2013). Vlijanie neblagoprijatnyh faktorov sredy na vozniknovenie sistemnoj gipoplazii jemali postojannyh zubov u detej. Moscow, 24.

[12] Popruzhenko, T. V., Klenovskaja, M. I. (2010). Profilaktika kariesa zubov s ispol'zovaniem sredstv, soderzhashhih ftoridy, kal'cij i fosfaty. Minsk: BGMU, 42-43.

[13] Gjorgievska, E. S., Nicholson, J. W. (2010). A preliminary study of enamel remineralization by dentifrices based on RECALDENT ${ }^{\mathrm{TM}}$ (CPP-ACP) and Novamin ${ }^{\circledR}$ (calcium-sodium-phosphosilicate). Acta Odontol. Latinoam, 23 (3), 234-239.

[14] Wu, G., Liu, X., Hou, Y. (2010). Analysis of the effect of CPP-ACP tooth mousse on enamel remineralization by circularly polarized images. The Angle Orthodontist, 80 (5), 933-938. doi: 10.2319/110509-624.1

[15] Zharkova, O. A., Lobkova, O. S. (2011). Remineralizirujushhaja terapija s ispol'zovaniem GC Tooth Mousse. Sovremennaja stomatologija, 2, 42-45. Available at: http://www.mednovosti.by/ journal.aspx?id=256

[16] Kysel'nykova, L. F., Marchenko, K. V. (2012). Zmina rivnja aktyvnosti lizocymu ta ureazy rotovoi' ridyny u ditej v procesi profilaktychnyh zahodiv. Ukrai'ns'kyj stomatologichnyj al'manah, 1, 1-8. 
[17] Fittal', R. K., Korol'ova, Zh. V. (2014). Sravnitel'naja ocenka klinicheskoj jeffektivnosti sovremennyh preparatov dlja remineralizirujushhej terapii. Sovremennye problemy nauki i obrazovanija.

[18] Joshi, S., Patil, N., Choudhari, S., Kulkarni, S. (2013). Comparative evaluation of remineralizing potential of three agents on artificially demineralized human enamel: An in vitro study. Journal of Conservative Dentistry, 16 (2), 116. doi: 10.4103/0972-0707.108185

[19] Ranjitkar, S., Rodriguez, J. M., Kaidonis, J. A., Richards, L. C., Townsend, G. C., Bartlett, D. W. (2009). The effect of casein phosphopeptide-amorphous calcium phosphate on erosive enamel and dentine wear by toothbrush abrasion. Journal of Dentistry, 37 (4), 250-254. doi: 10.1016/j.jdent.2008.11.013

[20] Oshiro, M., Yamaguchi, K., Takamizawa, T., Inage, H., Watanabe, T., Irokawa, A. et. al. (2007). Effect of CPP-ACP paste on tooth mineralization: an FE-SEM study. Journal of Oral Science, 49 (2), 115-120. doi: 10.2334 josnusd.49.115

\title{
USE OF METHODS OF MATHEMATIC STATISTICS FOR PROCESSING OF MEDICAL-BIOLOGICAL DATA FOR REVELATION OF THE ROLE OF CHEMICAL ELEMENTS IN ETHIOPATHOGENESIS OF HUMAN DISEASES
}

\author{
Anatolij Prykhodchenko \\ Department of Ecological Management \\ Dneprodzerzhinsk Institute of Economic and Management \\ 9 May str., 18, Dneprodzerzhinsk, Ukraine, 51934 \\ prykhod@mail.ru \\ Yulia Ulianovska \\ Department of Information Systems and Technology \\ University of Customs and Finance \\ 2/4 Vernadskogo str., Dnepropetrovsk, Ukraine, 49000 \\ uyv@rambler.ru \\ Vladislav Ulianoskiy \\ Student of I Medical department \\ Zaporozhye State Medical University \\ 26 Mayakovsky ave., Zaporozhye, Ukraine, 69035 \\ vlad.ulianovskiy@mail.ru
}

\begin{abstract}
Aim of paper was to appraise the possibility of use of the traditional mathematical statistics methods for biomedical data to processing for determining the role of aluminium, chrome, niobium and lead in functioning of human blood-forming system. An effect of the abovementioned microelements on immunocompetent and blast cells was examined.

Methods. To solve the indicated purposes, it were examined the venous blood leukoconcentrate in 48 of the examined persons. The standard methods of statistics were applied to the obtained data, namely the construction of spreading plot, elements of correlation and regression analysis.

Results. It was obtained, that the reaction of immunocompetent and blast cells is ambivalent and depends upon the level of micronutrient status in human organism. Micronutrient biogenic effect is observed upon its low concentration in blood. An abiogenic effect arises upon the high level of micronutrient status in biological media of human.

Conclusions. Notwithstanding the obtained results, the generally accepted approaches haven't provided the possibility to determine the faithful character of immunocompetent and blast cells reaction on the level of micronutrient status in human organism and require the elaboration and development of the new approaches considering the revealed nonlinear relation.
\end{abstract}

Keywords: hematopoietic system, leukoconcentrate venous blood, correlation analysis, regression analysis. 